NOT I C E

THIS DOCUMENT HAS BEEN REPRODUCED FROM MICROFICHE. ALTHOUGH IT IS RECOGNIZED THAT CERTAIN PORTIONS ARE ILLEGIBLE, IT IS BEING RELEASED IN THE INTEREST OF MAKING AVAILABLE AS MUCH INFORMATION AS POSSIBLE 


\section{Preliminary Results on Performance Testing of a Turbocharged Rotary Combustion Engine}

(NASA-TM-82772) PRELIMINARY RESULTS ON

P. R. Meng, W. J. Rice, H. J. Schock, and D. P. Pringle Lewis Research Center Cleveland, Ohio

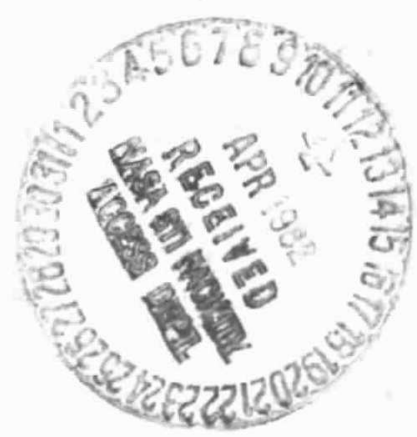

Prepared for the 1982 Society of Automotive Engineers Interuational Congress and Exposition Detroit, Michigan, February 22-26, 1982 
PRELIMINARY RESULTS ON PERFURMANCE TESIING OF A TURBOCHARGED

ROTARY COMBUSTION ENGINE

by P. P. Meng, W. J. Rice, H. J. Schock, and D. P. Pringle National Aeronautics and Space Administration

Lewis Research Center

Cleveland, Ohio 44135

\section{INTRODUCTION}

THE ROTARY COMBUSTION ENGINE (RCE) is of interest as a future powerplant for general aviation $(\mathrm{g} / \mathrm{a})$ and other small aircraft because of its turbine-like characteristics of simplicity, compactness, high specific power, improved fuel tolerance, low vibration and noise levels and clean, low drag installation characteristics. It is uniquely adaptable to stratified-charge, multifuel operation, with which it gives reasonable brake specific fuel consumption (BSFC) and exhaust emission lev els. This will help solve the fuels cost/ availability problem, which is generally considered the most important single issue facing general aviation today. An advanced rotary was selected in several recent mission studies $(1,2,3)$ * as being the most promising among several alternative candidate light aircraft engines for the future.

In the interest of evaluating the rotary engine for $g / a$, NASA contracted with Curtiss-Wright Corporation to test an existing naturally aspirated rotary aircraft engine. The test data on this carbureted $285 \mathrm{HP}(212 \mathrm{Kw})$, gasoline rotary aircraft engine showed that the BSFC and HC emissions were slightly high (4). BSFC at cruise conditions (77 percent power) was $0.54 \mathrm{lb} / \mathrm{BHP}-\mathrm{hr}$ $(328 \mathrm{~g} / \mathrm{Kw}-\mathrm{hr})$, about 20 percent higher than the best current aircraft piston engines of comparable power. However, the engine specific weight was 1.26 Ib/HP $(0.766 \mathrm{Kg} / \mathrm{Kw})$ which is at least 15 percent lower than today's best aircraft engines. A follow-on contract (5) which incorporated several slight modifications to this engine reduced the cruise BSFC to $0.45 \mathrm{lb} / \mathrm{BHP}-\mathrm{hr}$ $(274 \mathrm{~g} / \mathrm{Kw}-\mathrm{hr})$ while meeting the formerly proposed aircraft emission standards. Further advances in rotary engine technology have been made by

\footnotetext{
*Parenthetical numbers indicate references listed at end of this paper.
} 
Curtiss-Wright Corporation in the design and development of a $1500 \mathrm{HP}$ (1119 KW) stratified charge engine under a contract with the United States Marine Corps. This four rotor multifuel engine was successfully tested and has achieved the required design goals (6). This engine design was used as a baseline for further NASA rotary engine conceptual design studies $(7,8)$. The results of the Advanced Stratified-Charge Rotary Aircraft Engine Conceptual Design study have indicated that a highly advanced stratified-charge aircraft engine could achieve cruise BSFC's of $0.36 \mathrm{lb} / \mathrm{BHP}-\mathrm{hr}(219 \mathrm{~g} / \mathrm{Kw}-\mathrm{hr})$ at $250 \mathrm{BHP}$ $(186.4 \mathrm{Kw})$ with a specific weight of $0.80 \mathrm{lb} / \mathrm{BHP}(0.486 \mathrm{Kg} / \mathrm{Kw})$. The major specific weight improvement occurs from turbocharging a stratified charge, multifuel rotary engine (7). Turbocompounding can make further improvements in BSFC or specific weight for larger engines as discussed in Reference (8). At this time there are no experimental data available on the performance of turbocharged rotary engines. The preliminary test results obtained by turbocharging a Mazda non-emissions controlled, carbureted automotive engine with a commercially available turbocharger are presented in this report.

\section{FACILITY AND INSTRUMENTATION}

DESCRIPTION OF FACILITY - The test program was conducted at NASA Lewis Research Center. Figure 1 is a photograph of the rotary engine and turbocharger system tested. A description of this engine is given in Table 1.

A BAE commercial turbocharger kit (System No. 13-0000) was installed as specified in the manufacturer's instructions. Modifications were made to the inlet and exhaust systems to adapt them to the engine test facility. Boost pressure was maintained at a constant level over the range of engine speed by 
supplying pressurized air to the diaphragm of the waste gate. The wastegate is shown to the left of the turbine and just below the exhaust pipe in Figure 1. A four speed manual transmission was utilized to couple the engine to a $250 \mathrm{HP}(186.4 \mathrm{KW})$ dynamometer. This dynamometer is limited to a maximum speed of 6000 RPM. This limitation prevented testing of the engine at its naturally aspirated rated speed of 7000 RPM without shifting the transmission to a lower gear. Tests were conducted in fourth gear (direct-drive) to eliminate changes in frictional characteristics of the transmission. Transmissions of this type have been shown to have efficiencies of 98 percent in direct-drive at high power levels (9); however, for the purposes of this paper a 100 percent transmission efficiency is assumed. This results in consistent but slightly pessimistic data.

Complete conventional pressure, temperature and flow instrumentation was installed on the engine in addition to the special NASA-developed combustion instrumentation which will be discussed later in this report. Automatic control systems were utilized for engine speed, dynamometer load, and coolant discharge temperature. Load was measured with a reaction load cell. An absolute position optical shaft angle encoder was installed on the front of the engine and was belt-driven at a $3: 2$ ratio by the eccentric shaft to provide rotor angle information. The $3: 2$ ratio was used to convert the $1080^{\circ}$ crank degree cycle of the RCE to $720^{\circ}$ so as to be analogous to the four stroke piston engine cycle.

Exhaust emissions were measured by a Scott Research Laboratcries Test. Console which incorporated the following equipment: 
A Scott Model 415 Total HC Analyzer

A Scott Model 250 Paramagnetic $\mathrm{O}_{2}$ Detector

A Scott Model $125 \quad \mathrm{NO}_{\mathrm{NO}}$ Analyzer

A Beckman Model $864 \quad \mathrm{CO}_{2}$ Analyzer

A Beckman Model 865 CO Analyzer

Engine operation was monitored on the alplianumeric CRT displays in the control room. A micro-processor at the test cell was utilized to interface with a central minicomputer which performed on line calculations and cont ni uusly updated the CRT displays. An IBM-3033 was used for necessary post-run processing and graphical analysis of collected data.

SPECIAL INSTRUMENTATION - In addition to the standard instrumentation, unique NASA-developed combustion diagnostic instrumentation $(10,11)$ was used to obtain data on key combustion parameters. Real time measurements were made of indicated mean effective pressure (IMEP), pumping mean effective pressure (PMEP), peak cycle pressure, angle of occurrence of peak pressure and the spark timing. This instrumentation system is capable of measuring these parameters on a cycle-by-cycle basis. It is also valuable in determining the effects of changes in global air-fuel ratio, combustion chamber shape, and spark advance on the combustion process. Data is presented in histogram form on an oscilloscope and computations of mean, standard deviation, maximum and minimum values are available as digital output. Figure 2 shows a typical histogram of IMEPT (IMEPT = IMEP + PMEP) for the engine tested. This diagnostic instrumentation as installed in the control room, is shown in the foreground of Figure 3. 
Pressure-volume diagrams are also generated by the diagnostic instrumentation. Figure 4 a shows a typical diagram oi the complete four stroke cycle and Figure $4 \mathrm{~b}$ shows a blowup of the pumping loop of the diagram for a condition when the engine was in turbocharged operation at 4 ps $i$ $(27.6 \mathrm{kpa})$ boost. The diagnostic equipment would also be useful for tuning the inlet and/or exhaust systems; however, no attempt was made to do this during this series of tests.

4 new feature of this system was the ability to make measurements in any of the three combustion faces of the rotor by electronically switching to the face of interest without stopping the engine. This feature allowed measurements of IMEPT for the three rotor faces while the engine was at the same thermal equilibrium point. Figure 5 shows there is little face to face variation in IMEPT over the region tested. Each of the nine points on this graph represents the average of one hundred consecutive measurements of IMEPT. Maximum variability defined as (max-min)/average was 2.8 percent at 5000 RPM.

TEST PROCEDURE - The engine was operated at steady state conditions (speed, load and water temperature), at which time data were recorded and oscilloscope traces from the combustion instrumentation were photographed. Steady state was said to exist when there was agreement of \pm 5 percent between the air/fuel (A/F) ratio from the direct measurement of air flow and fuel flow and the A/F ratio calculated from the method of Spindt (12).

After the engine was brought to the test speed, load and boost were applied until the desired boost was attained at a given load. Spark was advanced to the point of audible knock and then retarded slightly. (The trailing spark plug was fired 10 eccentric shaft degrees later than the 
leading plug.) Initial tests were conducted using water injection to control knock. This method was found to be very effective; however, the emission analyzer was adversely affected by the additional water from injection and the practice was discontinued. None of the test conditions for the data presented in this report include water injection.

EFFECT OF BOOST - The data in Figure 6 show the range of speeds and jowers (BHP) over which the engine was tested. The upper curve shows the output of the turbocharged engine at boost pressures of up to $7 \mathrm{psi}(48.3 \mathrm{kpa})$, and the lower curve shows the wise-open throttle performance of the engine naturally aspirated. A comparison of the performance of this engine in the turbocharged configuration with the naturally aspirated system shows a 36 percent increase in power from $112.5 \mathrm{BHP}(83.9 \mathrm{KW})$ to $153 \mathrm{BHP}(114 \mathrm{KW})$ at a nominal speed of 5900 RPM. Power levels at the three boost levels of 3,5 , and 7 psi $(20.7$, 34.5 , and $48.3 \mathrm{kpa}$ ) over a range of speed from 3000 to 6000 RPM are shown in Figure 7.

COOLANT TEMPERATURE EFFECT ON BSFC - Researchers at General Motors (13) have shown that an increase in coolant temperature from $190^{\circ} \mathrm{F}$ to $280^{\circ} \mathrm{F}\left(88^{\circ}\right.$ C to $138^{\circ} \mathrm{C}$ ) resulted in reductions in hydroca:bon emissions by a factor of 3 in a rotary engine. Another recent publication (14) showed a significant improvement in BSFC as coolant temperature was increased from $140^{\circ} \mathrm{F}$ to $212^{\circ} \mathrm{F}$ $\left(60^{\circ} \mathrm{C}\right.$ to $\left.100^{\circ} \mathrm{C}\right)$. A reduction in $\mathrm{HC}$ emissions was also observed in this study. In both these instances, the tests were cunducted over a rangc of speeds and loads necessary for road load operation of an automobile. It was our intention to determine whether or not the fuel economy at the higher speeds and power ranges of interest for aircraft application would also be 
affected by changes in housing coolant temperature. A thermocouple installed near the epitroichoidal surface of the rotor housing (Figure 8) was used to measure the surface temperature during testing.

Coolant discharge temperatures are shown in Figure 9 and corresponding housing thermocouple readings are shown in Figure 10. Conditions studied were at a constant power of $105 \mathrm{BHP}(78.3 \mathrm{KW})$ and speeds ranging from 3500 to 5900 RPM. Figure 11 shows that no discernible differences in fuel economy were found as the coolant discharge temperature changes from $180^{\circ} \mathrm{F}$ to $210^{\circ} \mathrm{F}\left(82^{n}\right.$ C to $99^{\circ}$ C).

It is interesting to note in Figure 12 that at a given speed with increasing coolant temperature there appears to be a general reduction in hydrocarbons. The rich carburetor jets used in this testing were used to keep turbine inlet temperatures within tolerable limits. For each of the speeds, there : $: a s$ no recognizable change in A/F ratio which would have biased this comparison.

EFFECT OF A/F RATIO ON BSFC AT CRUISE CONDITIONS (105 BHP) (78.3 KW) Smaller carburetor jets were installed to determine their effect on BSFC and turbine inlet temperature. Figure 13 shows the variation in A/F ratio for the two sets of carburetor jets. Coolant discharge temperature from the engine block was maintained at $180^{\circ} \mathrm{F}$ for all conditions. The lower curve is for the larger jets and the upper curve for the smaller jets. Figure 14 shows the corresponding BSFCs for these conditions. The most economical point on the lower curve is approximately $0.45 \mathrm{lbm} / \mathrm{HP}-\mathrm{hr}(274 \mathrm{~g} / \mathrm{KW}-\mathrm{hr})$ compared to 0.54 $(328 \mathrm{~g} / \mathrm{Kw}-\mathrm{hr})$ at the same power and speed but lower A/F ratio. Clearly, one would prefer to operate at the leaner condition and realize the 16 percent improvement in fuel consumption. However, the normal continuous operation 
temperature 1 imit of typical turbochargers is $1650^{\circ} \mathrm{F}\left(8 \mathrm{99} 9^{\circ} \mathrm{C}\right)$, and examination of the data in Figure 15 shows that the tempi:ature limit was exceeded by up to $200^{\circ} \mathrm{F}\left(111^{\circ} \mathrm{C}\right)$ while operating the eng we at the lean conditions. This increase in turbine inlet temperature at lean operating conditions in combination with high stresses over an extanded period of time may cause turbine fallure.

The most desirable way to reduce the Exhaust Gas Teriserature (EGT) is to devise a method of burning the fuel earlier in the expansion stroks. This means that more of the energy would be extracted from the air-fuel mixture as work. This action would have to take place withis the structural limitaticns of the engine.

DIESEL VS. ROTARY ENGINE ENERGY USAGE - Figure 16 gives an energy balance for the RC engine tested. This graph is for a constant power of 105 BHP (78.3 K.w) at $155 \mathrm{psi}(1069 \mathrm{kpa})$ BMEP and $3990 \mathrm{RPM}$. The spark was advanced to MBT timing for this test condition. This figure shows how the energy input into the rotary combustion engine can be divides among useful work, heat rejection to exhaust, coolant and oil, and "miscellaneous." The latter term includes the previously-discussed transmission losses, as well amounts for convection, radiation and windage. Similar results are shown on Figure 17 for a turbocharged direct-injection AVL research diesel engine (description in Table 2). In a gross sense, these graphs give an indication of where research effort should be expended. The rotary engine tested is compared to the diesel since one would like to approach the high efficiency of the diesel engine in the lightweight rotary for aircraft applications. However, it should be kept in mind that this heat balance comparison was made with a stratified charge 
combustion diesel engine and a homogeneously charged rotary combustion engine which will account for some of the differences in energy recovery. Some of the discussion which follows is admittedly speculative in nature but it does represent an attempt to describe the important aspects of combustion and efficiency of the diesel relative to the rotary engine.

The rotary engine shows an average brake energy recovery rate of 29 percent after the transmission while that for the diesel is 40 percent. The diesel operates at a much higher compression ratio, which with its injection controlled rate of heat release results in a more favorable expansion ratio.

The cominact combustion volume of the AVL diesel coupled with the high swirl rates produced by the shrouded valves provide an ideal environment for combustion. The real question at hand is how does one go about improving the efficiency of the RCF while taking advantage of its high power to weight ratio. The controlled and high rates of pressure rise associated with the diesel engine during combustion are clearly a result of the ability to tailor the fuel injection schedule to a prescribed pattern. Thus, for the direct injected diesel engine the heat release schedule is determined by the structural constraints of the engine. In homogeneously charged spark ignition engines, the heat release schedule and $A / F$ ratio for a given operating point are determined by the vagaries of combustion in a lean, turbulent mixture rather than by a fuel injection schedule.

Danieli (15) claims that the biggest loss in the RCE relative to the ideal fuel-air cycle is due to the finite combustion speed. Work by Cichanowitz and Sawyer (16) showed a slight improvement in indicated thermal efficiency when operating a rotary engine with hydrogen addition of up to 20 percent by mass to improve flame speed at low power levels. This effect should be studied at 
higher power levels $100 \mathrm{HP}(75 \mathrm{~kW})$ where "quenching effects" may not be as significant. Late burning means high heat transfer rates through the expansion stroke, as well as an effective expansion ratio that is less than a constant volume heat addition expansion ratio. It is thus important to determine how the fuel can be burned earlier in the expansion stroke.

Heat rejection to the coolant in the rotary tested, expressed as a percentage of input energy, was about 18 percent with an additional 7 percent rejected via the oil cooler for a total of 25 percent. This compares to a 17 percent energy loss in the diesel: 9 percent lost to the engine block, 6 percent to the head and about 2 percent through the oil cooler.

A comparison of average piston speed with average rotor tip speed at a constant angular combustion system velocity of 1500 RPM is now made. At a 4500 RPM eccentric shaft speed which is 1500 RPM rotor angular velocity, the average velocity of the rotor $t$ ip is about $3700 \mathrm{ft} / \mathrm{min}(18.8 \mathrm{~m} / \mathrm{sec})$ for the engine tested. The average piston speed at 1500 RPM for the AVL diesel engine is $1200 \mathrm{ft} / \mathrm{min}(6.1 \mathrm{~m} / \mathrm{sec})$. The assumption is now made that the average rotor tip and piston velocities are indicative of local gas velocities in the combustion system of interest. Convective heat transfer coefficients are known to vary directly with Reynolds number; thus, the higher energy lost in heat transfer is likely to be accounted for at least in part by the higher gas velocities associated with the geometry of an engine like the rotary. Frequently, a high surface to volume ratio is blamed for the large heat losses and low efficiencies in the RCE.

The average amount of energy lost by heat rejection to the 0 il is 7.3 percent. Thermally insulating the rotor surface is one method of reaucing heat transfer to the oil. A second method to reduce the heat loss of the 
rotary combustion engine is to devise a way to operate the combustion surface of the rotor housing at higher temperatures. This could be accomplished by elevation of the coolant temperature and/or by thermally insulating the combustion section of the rotor housing. The resulting higher rotor surf ace temperatures should facilitate oxidation of hydrocarbons which may become absorbed on the oil film covering the rotor surface. In any event, the higher operating temperature of the combustion surface of the housing will require either a higher temperature apex seal lubricant or a different material for the apex seals or possibly both of these. In all probability, a high fraction of the energy saved by reducing the internal heat loss will generally appear in the exhaust. This gives the engine designer the opportunity to incorporate devices such as turbochargers and compounding turbines to further improve the efficiency and specific weight of the rotary engine.

SUMMARY AND CONCLUSIONS

1. At $5900 \mathrm{RPM}$, a 36 percent power increase was obtained by turbocharging the rotary engine tested with 7 psi $(48.3 \mathrm{kpa})$ boost. Similar power increases were found over the entire range of speeds tested.

2. Under lear, operating cruise conditions of $105 \mathrm{BHP}(78 \mathrm{Kw}$ ) a BSFC of $0.45 \mathrm{lbm} / \mathrm{HP}-\mathrm{hr}(274 \mathrm{~g} / \mathrm{Kw}-\mathrm{hr})$ was measured for the turbocharged engine tested. In the naturally aspirated engine configuration a BSFC of $0.55 \mathrm{lb} / \mathrm{BHP}-\mathrm{hr}$ (335 $g / K W-h r)$ was measured for this power level at 5080 RPM.

3. The rotary engine tested had an average thermal efficiency of 29 percent while the diesel showed an efficiency of 40 percent for the data compared. The biggest difference in input energy loss between the two engines 
was in the rejection of heat to the combustion chamber. For the rotary 25 percent o: the input energy was rejerted to the rotor and rotor housing and for the diesel engine 17 percent of the input energy was rejected to the piston and cylinder walls.

4. An important reason for the low efficiency of the rotary engine is the slow combustion as compared to the diese 1. Increases in efficiency of the RCE will require controlled combustion, improved thermal barriers and advances in sealing techniques.

5. For a power output of $105 \mathrm{HP}(78 \mathrm{kw})$ coclant temperature increases of less than $30^{\circ} \mathrm{F}\left(17^{\circ} \mathrm{C}\right)$ had little effect on fuel economy. A slight reduction in hydrocarbon emissions was noted.

6. Combustion diagnostic instrumentation showed that rotor face-to-face variability in IMEPT was less than 3 percent for the condition tested. 
REFERENCES

1. T. J. Wickenheiser, G. Knip, R. M. Plencner, and H. C. Strack, "Comparisons of Four Alternative Powerplant Types for Future General Aviation Aircraft," HASA Lewis Research Center, NASA TH-81584, October 1980.

2. G. L. Huggins and D. R. Ellis, "Advanced General Aviation Comparative Engine/Airframe Study," prepared under Contract NAS3-22221, September 1981.

3. L. A. Znroczek, "Advanced General Aviation Comparative Engine/Airfrane Study," prepared under Contract NAS3-22220, September 1981.

4. C. Jones, "The Rotating Combustion Engine - Compact Lightweight Power for Aircraft," SAE Paper 670194, November 1966.

5. R. K. Lamping, I. Manning, D. Myers and B. Tjoa, "Performance, Emissions, and Physical Characteristics of a Rotating Combustion Aircraft Engine, Supplement A," Curtiss-Hright Corporation, Hood-Ridge, NJ, CH-UIR-76C.2803, May 1980 (NASA CR-135119).

6. C. Jones and M. Berkowitz, "Multifuel Rotary Aircraft Engine," AIAA Paper 80-1237, June 1980.

7. P. Badgley, D. R. Ellis, et al, "Advanced Stratified Charge Rotary Engine Design Study," NASA CR-165398, July 1981.

8. M. Berkowitz, C. Jones and D. Myers, "Study of Advanced Rotary Combustion Engines for Commuter Aircraft," MASA CR-165399, July 1981.

9. 11. P. Bujold, "Small Passenger Car Transmission Test - Chevrolet Luv Transmission," Eaton Corporation, Southfield, MI, ERC-LIB-80121, June 1980 (NASA CR-159882). 
10. II. J. Rice, and A. G. Birchenough, "Modular Instrumentation Systen for Real-Time Measurements and Control on Reciprocating Engines," NASA Lewis Pesearch Center, NASA TP-1757, Novenber 1980.

11. H. J. Schock, II. J. Rice, and P. R. Meng, "Experimental Analysis of IMEP in a Rotary Combustion Engine - Indicated lhean Effective Pressure," SAE Paper 810150, February 1981.

12. R. S. Spindt, "Air Fuel Ratios From Exhaust Gas Analysis," SAE Paper 650507, May 1965.

13. H. A. Burley, M. R. Heloeny, and T. L. Stark, "Sources of Hydrocarbon Emissions in Rotary Engines," SAE Paper 780419, February 1978.

14. K.. Yamamoto and T. Muroki, "Development on Exhaust Emissions and Fuel Econony of the Rotary Engine at Toyo Kogo," SAE Paper 780417, February 1978.

15. G. A. Danieli, J. C. Keck, and J. B. Heywood, "Experimental and Theoretical Analysis of Hankel Engine Performance," SAE Paper 780416, February 1978.

16. J. E. Cichanowicz and R. F. Sawyer, "Rotary Engine Combustion With Hydrogen Addition," SAE Paper 760611, August 1976. 


\section{Table 1}

Mazda 12B Spark-Ignition Engine

Compression Ratio 9.4:1

Rating Naturally Aspirated $110 \mathrm{HP}$ at 7000

Output Turbocharged $153 \mathrm{HP}$ at $5900 \mathrm{RPM}$

Carburetted, 2 Rotor, 35 in $3 /$ Rotor $* 573$

cc/rotor

Fuel: Clear Indolene

RON 97.6, MON 87.6

Table 2

AVL-521 Research Diesel Engine

Compression Ratio $=17.3 / 1$

80 BHP at 3000 RPM Supercharged to 47.7 PSIA

Fuel Injected-Single Cylinder, 87.8 in $^{3}$ Disp.

Fuel No. 2 Diesel

* 35 in $^{3}=$ Maximum Volume - Minimum Volume

for 1 Rotor Face 


\section{BLACK AND WHITE PHOTOGRAPH}

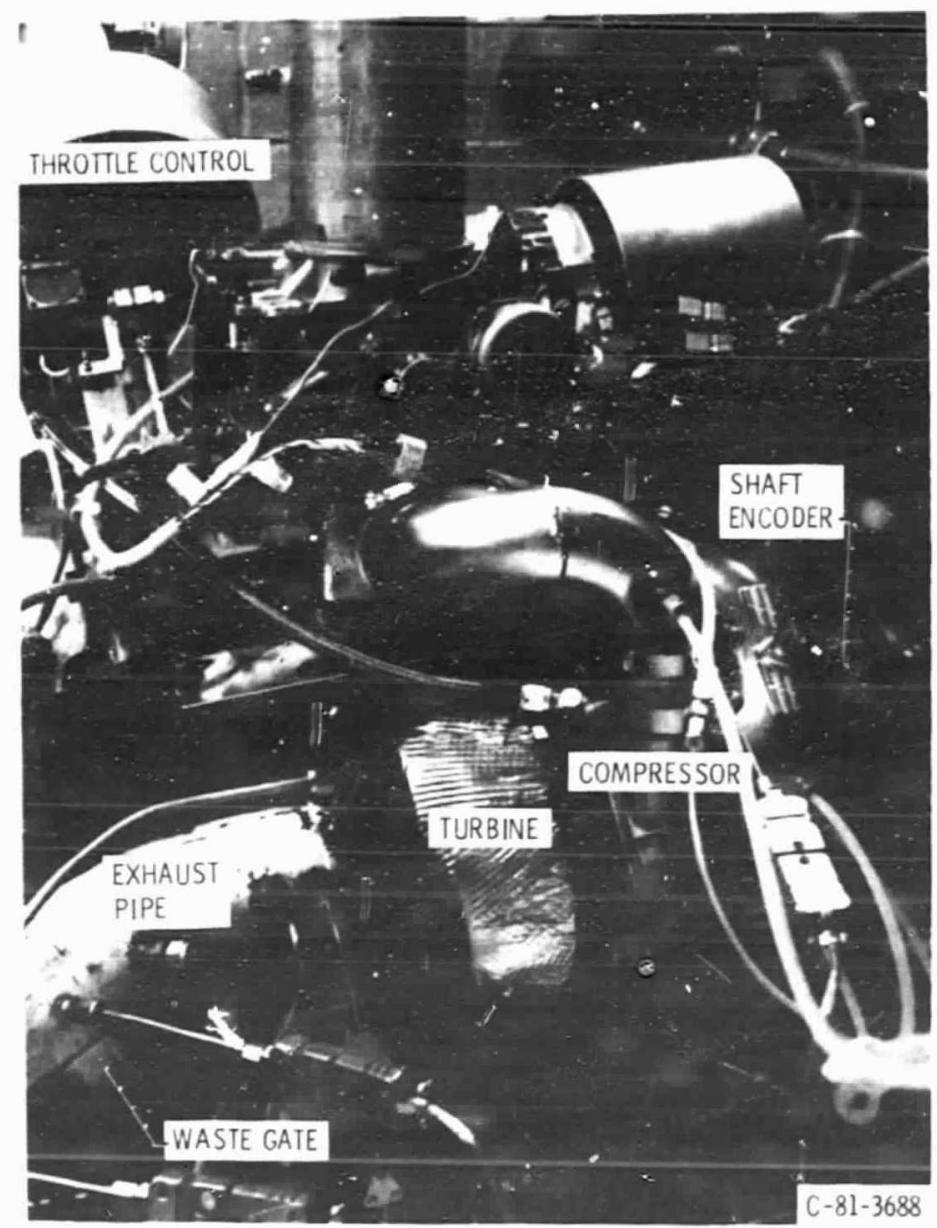

Figure 1. - Rotary engine with turbocharger system installed.

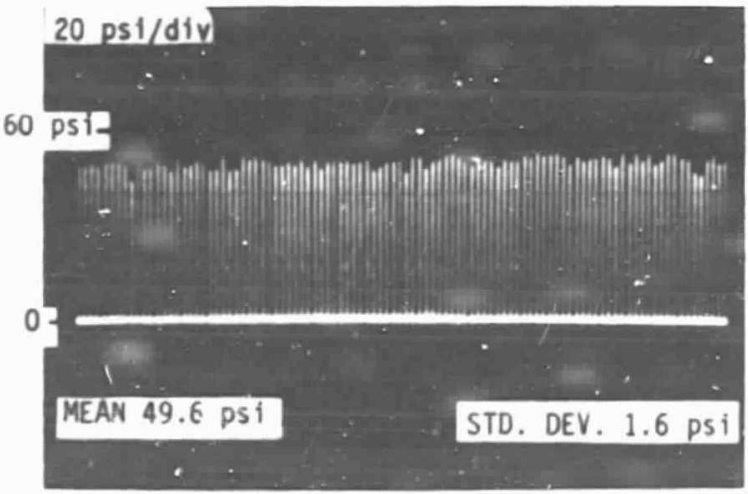

Figure 2. Typical bargraph of one hundred consecutive cycle values of IMEPT for rotary engine. 

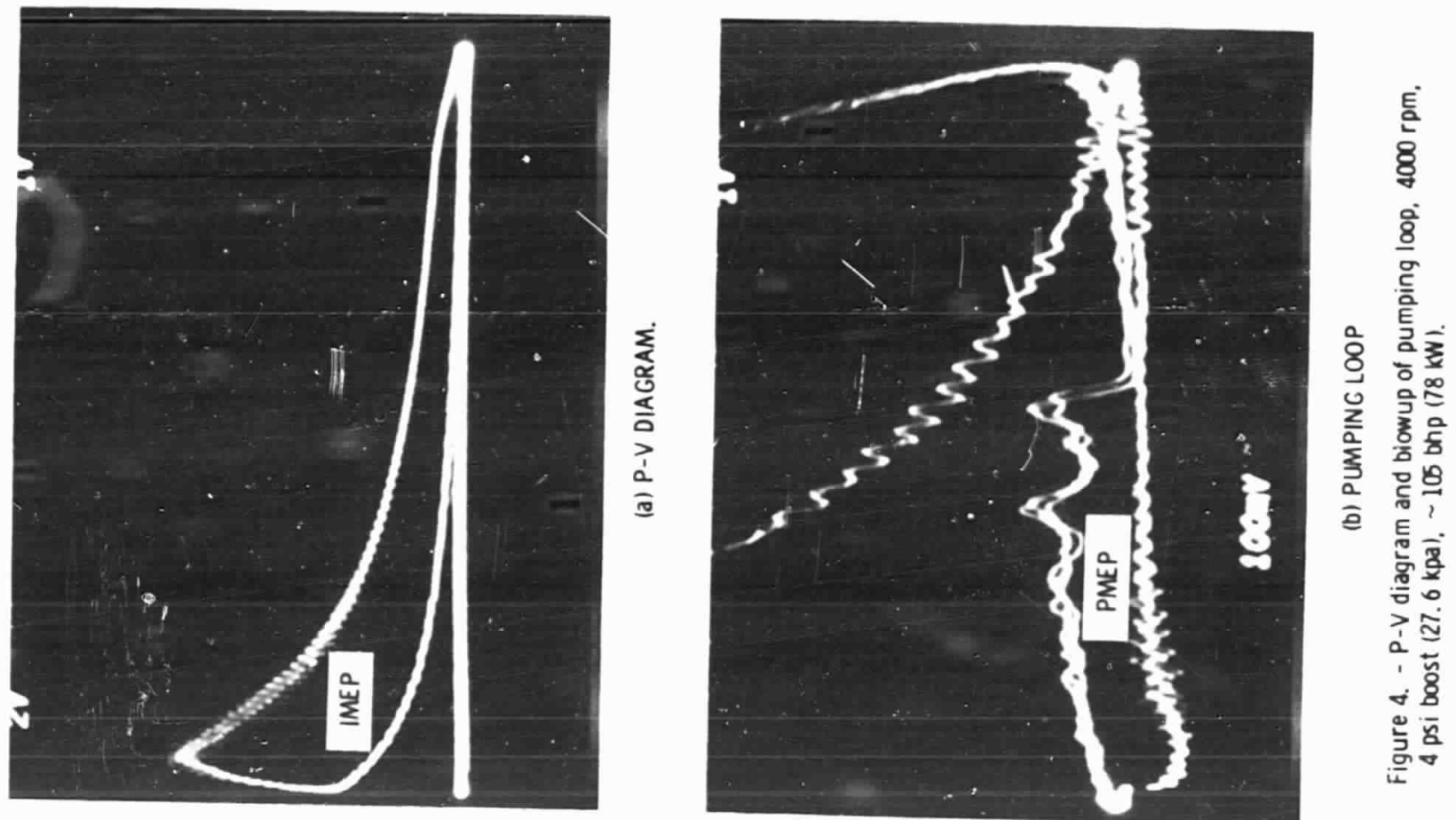

ORIGINAL PAGE

BLACK AND WHITE PHOTOGRAPH

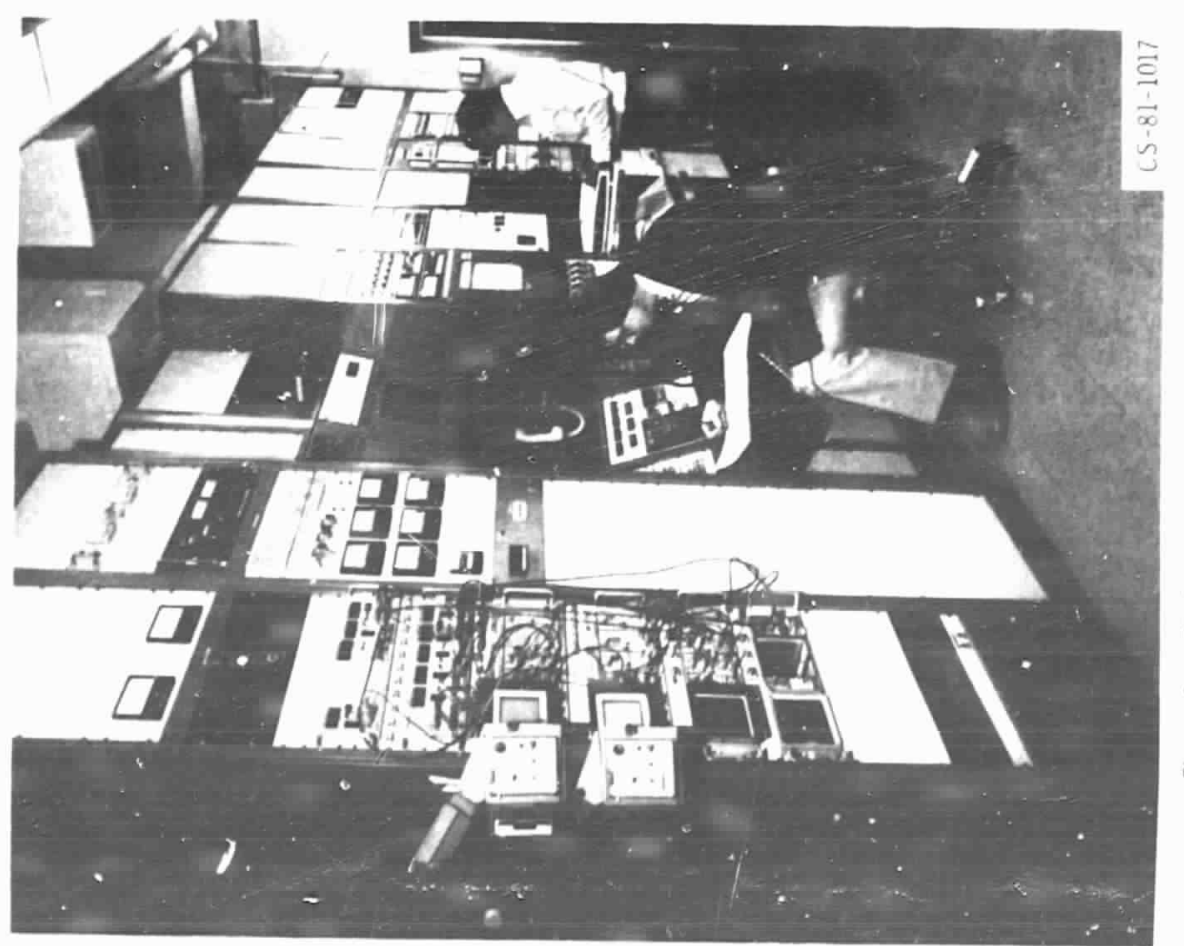




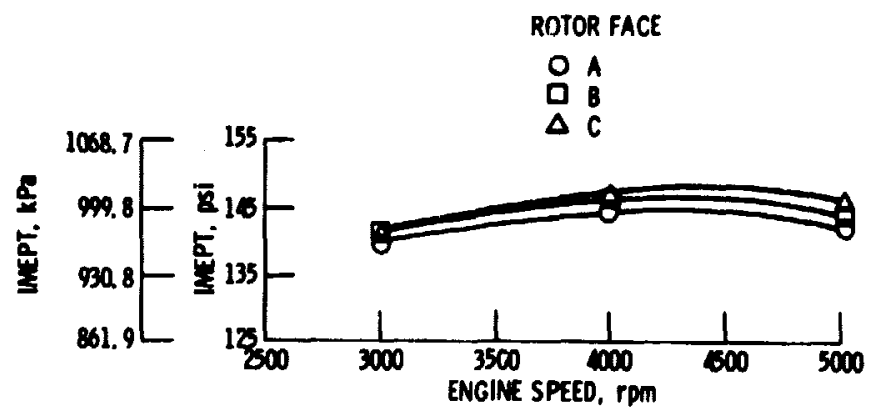

Figure 5. - Variabillty of IMEPT on rotor taces.

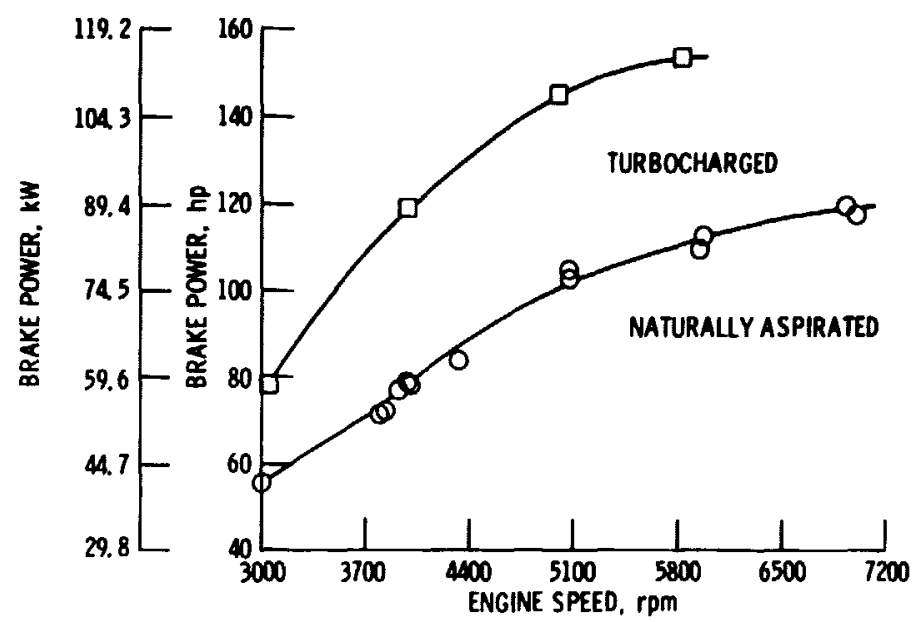

Figure 6. - Power output of turbocharged and naturally aspirated rotary combustion engine as a function of speed.

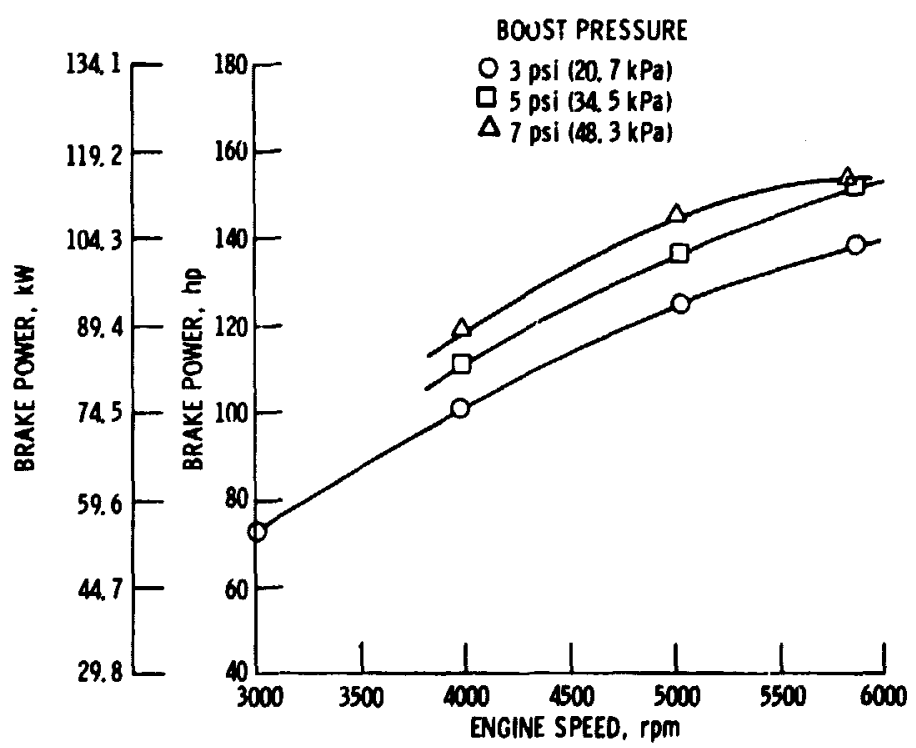

Figure 7. - Power output of rotary combustion engine at verious levels of boost pressure. 


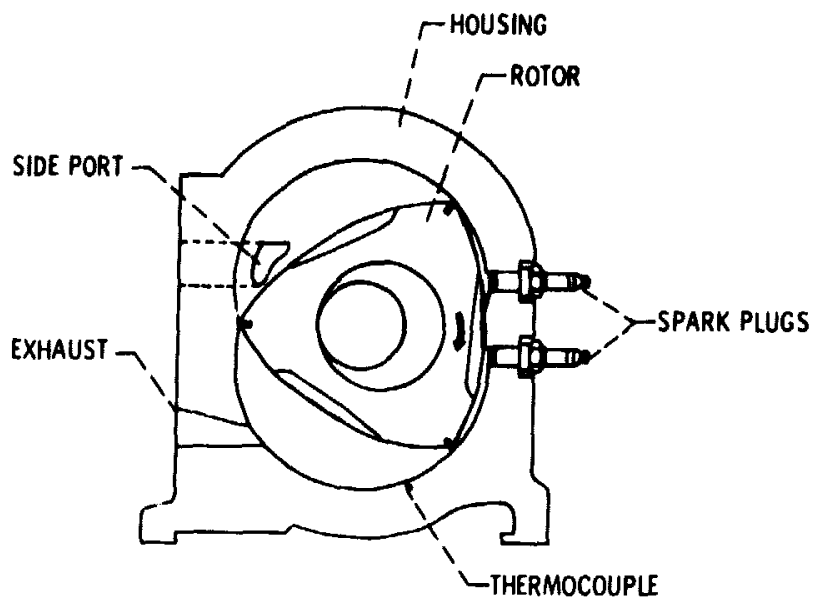

Figure 8. - Location of thermocouple on rotor housing surface.

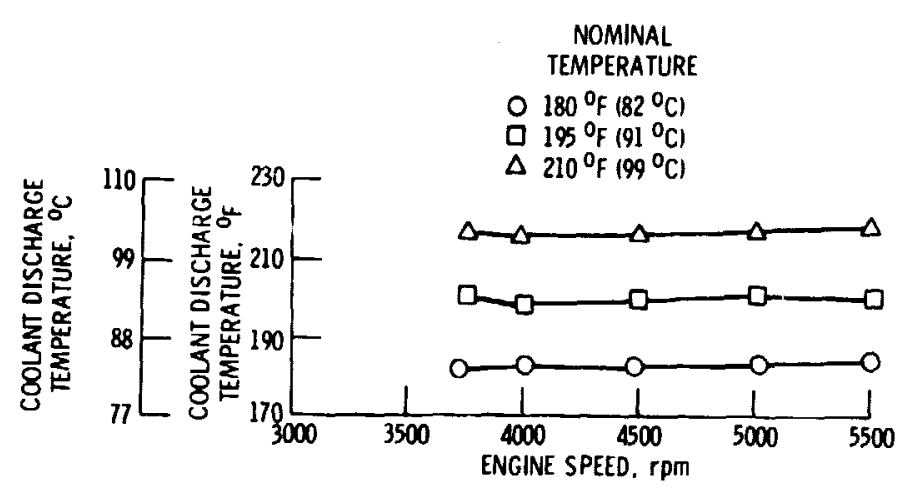

Figure 9. - Coolant discharge temperature vs. spead at a constant power of $105 \mathrm{bhp}, 78 \mathrm{~kW}$.

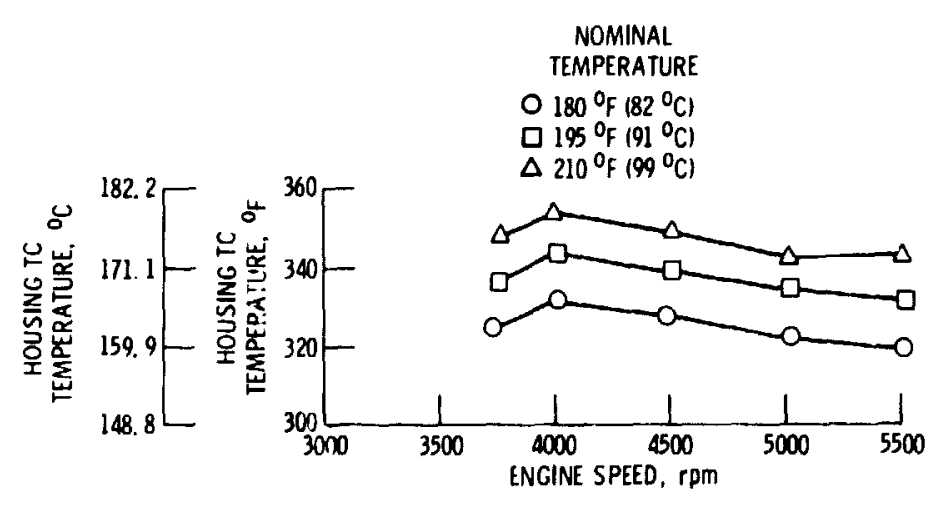

Figure 10. - Variation in housing surface temperature with speed at three coolant discharge temperatures. 


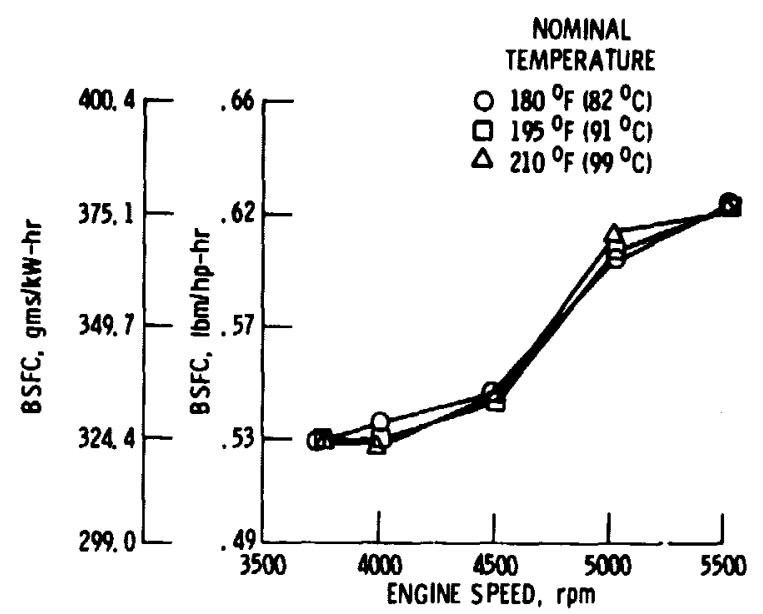

Figure 11. - Variation of BSFC with coolant discharge temperature at constant power of $105 \mathrm{bhp}, 78 \mathrm{~kW}$.

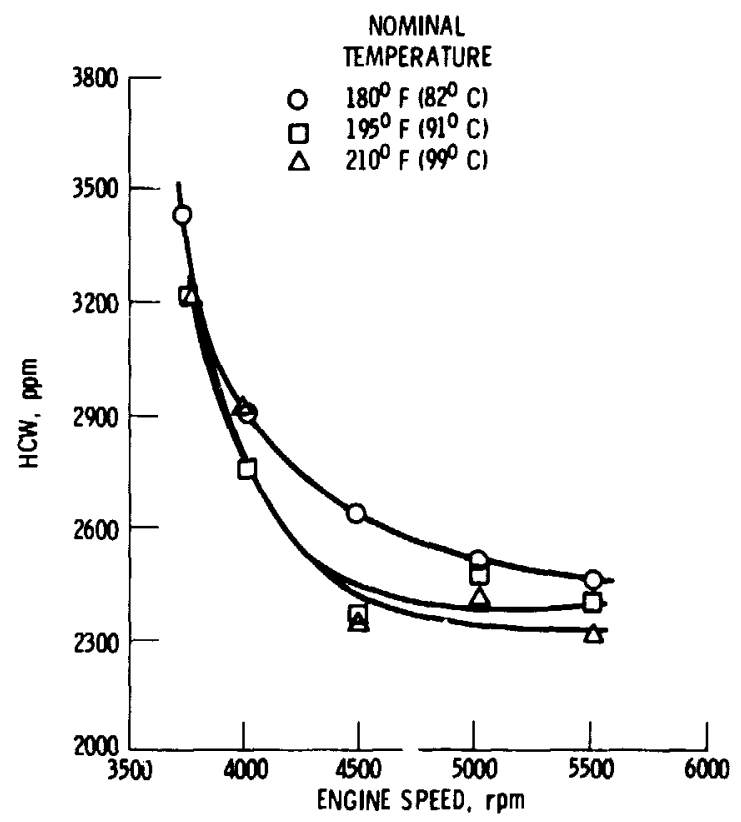

Figure 12. - Varlation of hydrocarbon emissions with coolant discharge temperature at constant power of 105 bhp (78 kW). 


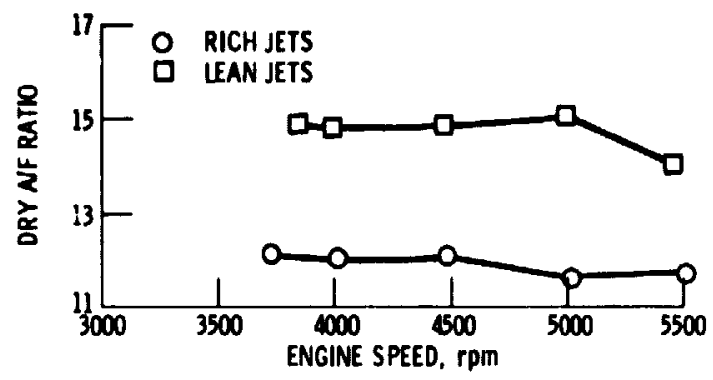

Figure 13. - Air-fuel ratio vs. speed for rich and lean carburetor jets at a constant power of 105 bhp $(78.3 \mathrm{~kW})$.

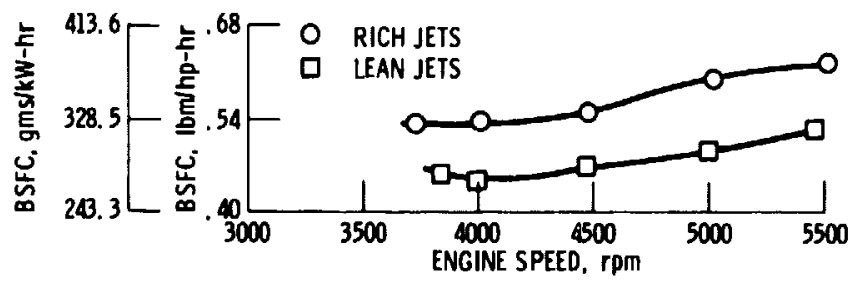

Figure 14. - BSFC vs. speed for rich and lean carburetor jets at constant power of 105 bhp $(78 \mathrm{~kW})$.

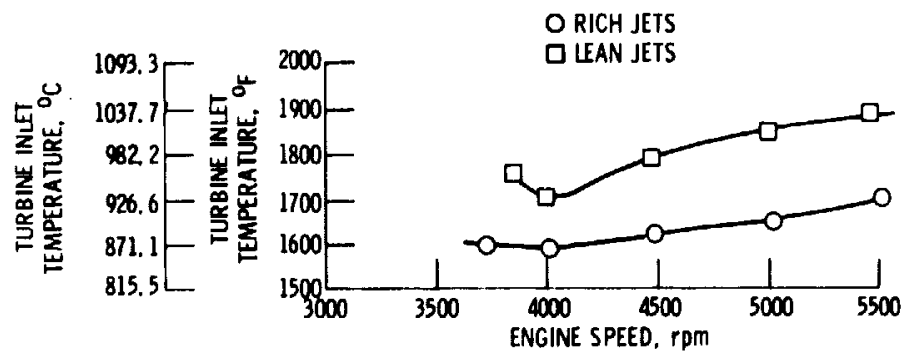

Figure 15. - Turbine inlet temperature vs, speed for rich and lean carburetor jets at a constant power of 105 bhp, $78 \mathrm{~kW}$. 


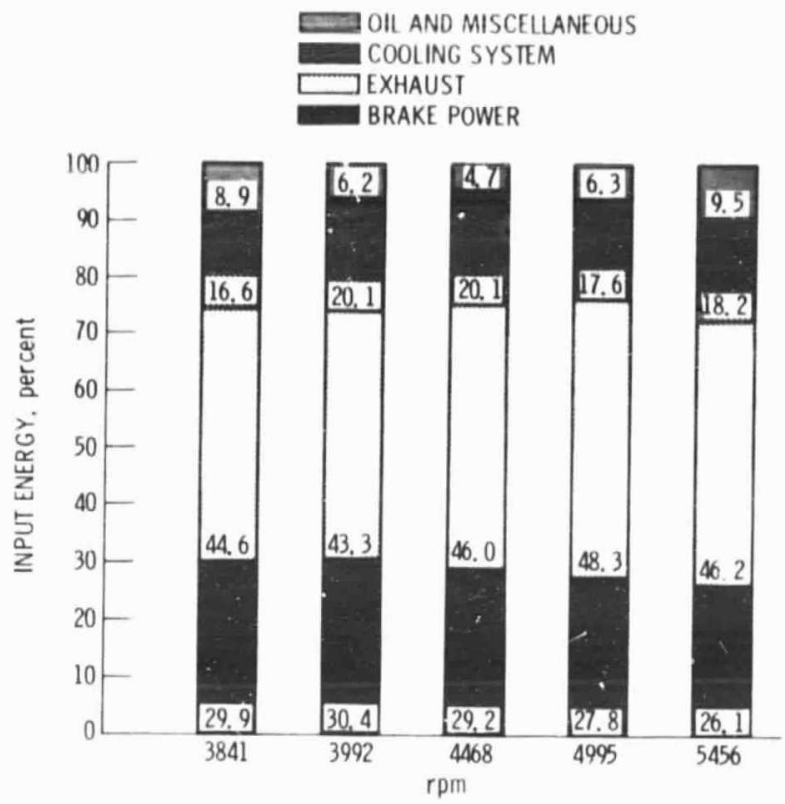

Figure lt. - Energy balance of turbocharged rotary combustion engine at constant power of $105 \mathrm{bhp}, 78 \mathrm{~kW}$.

\section{ORIGINAL PAGE IS \\ OF POOR QUALTTY}

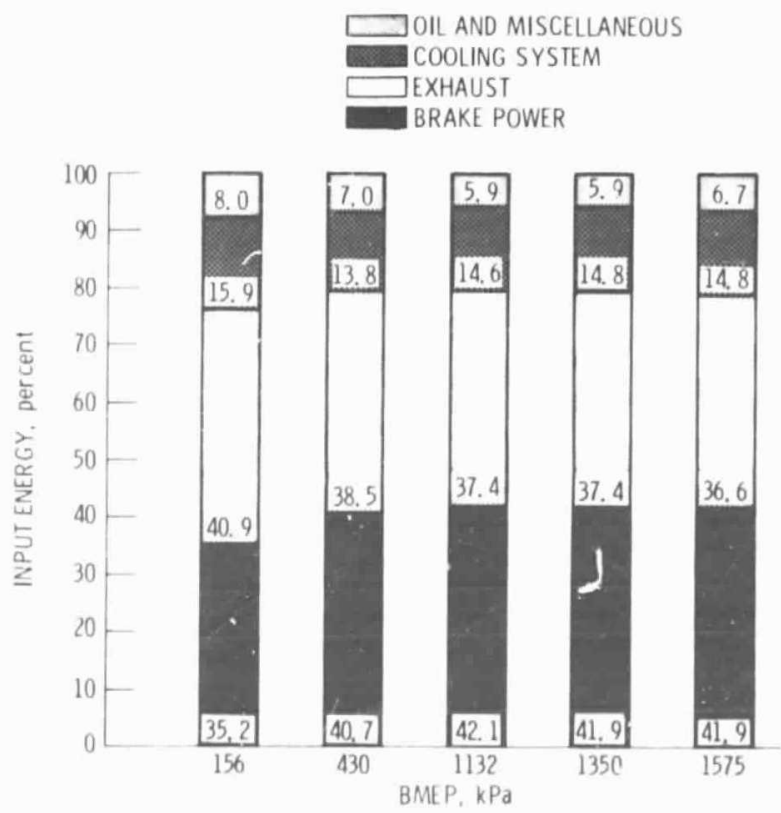

Figure 17. - Energy balance of turbocharged diesel at constant speed of $1500 \mathrm{rpm}$. 